\title{
Comprehension Levels of Reading Exercises in Look Ahead English Coursebooks
}

\author{
Ria Elfrida Shinta Rouli Sirait \\ Student of Graduate School of English Education Department \\ Widya Mandala Catholic University, Indonesia \\ E-mail: shintasirait86@gmail.com
}

Received: August 27, 2014 Accepted: September 11, $2014 \quad$ Published: September 12, 2014

doi:10.5296/ijele.v2i2.6307 URL: http://dx.doi.org/10.5296/ijele.v2i2.6307

\begin{abstract}
Reading comprehension exercises are important to be presented following a reading text in a course book to help students develop their competences in comprehending the text. In addition, considering the psychological factor of the students, English syllabus of reading in KTSP suggests senior high school students to be able to comprehend the reading text critically. This study evaluated the comprehension levels of exercises in Look Ahead 1, 2 and 3. Evaluated using Anderson and Krathwol's Reading Comprehension Taxonomy, the lower-order thinking levels of the reading taxonomy which were Remembering, Understanding, and Application taxonomies dominated the exercises in Look Ahead coursebooks. While there were only low numbers of the higher-order thinking exercises which included Analyzing, Evaluating, and Creating presented in the course books.
\end{abstract}

Keywords: comprehension level, exercise. 


\section{Introduction}

In EFL setting, instructional materials are the main instrument used to achieve the English objective in the teaching learning process. It is in line with Harjanto et al (2011) who states that instructional materials in EFL setting are the foundation of school instruction and the primary source of information for teachers and students. There are many instructional materials can be used such as course book, work book, newspapers, magazines and others. However, compared to the other types of instructional materials, course books have the most crucial role to achieve the English learning objectives. It is in line with Higgs (1982) who says that it could not be denied that course book is an essential part in curriculum, including in learning foreign language.

There are varieties of English course books available at the market which the publishers claim that the materials are based on and meet the objectives of current curriculum, KTSP 2006, such as Look Ahead coursebooks. These coursebooks are used by some qualified senior high schools in Surabaya such as SMAK St Louis 1, SMAK St Louis 2, SMKN 9, SMA Al Hikmah, SMAK Frateran and SMA Muhammadiyah 1 in Sidoarjo. Furthermore, Erlangga as the publisher of this book claims that Look Ahead has been made based on KTSP 2006. They claim that the materials in the Look Ahead are compatible with the English basic competencies stated by the Minister of Education in the Act of Ministry Education no. 22/ 2006 and standard of graduate students in Act of Ministry Education no. 23/ 2006. However, the claims of the publishers should not be taken for granted since they have not ever published the result of the evaluation which shows that the materials in Look Ahead are relevant to the English basic competencies. Therefore, evaluation toward the materials in Look Ahead is important to be conducted. The weaknesses and strengths of the materials in Look Ahead evaluated in this study might give insights for teachers who are using this course book.

However, not all materials are evaluated in this study. The materials evaluated are only the reading materials. Reading is necessary to be evaluated since reading is considered as first step in learning other skills. The reading materials evaluated were only reading exercises in the Look Ahead coursebooks. The reading exercises presented in the Look Ahead should guide students to be able to critically comprehend a text as suggested by the English syllabus of KTSP. Previous curriculum explicitly stated the indicators of English reading in the syllabus. Students who achieved the indicators were considered succeed to achieve the basic competence. However, KTSP as the latest curriculum of this country does not explicitly mention indicators that should be achieved by the students. Therefore, Anderson and

Krathwol's Reading Taxonomy is used in this study to evaluate levels of comprehension of the exercises.

\section{The Coursebook Evaluation}

Since the role of the course book is very crucial and the numbers of imported and domestically course book are a lot, the process of selecting and evaluating the course book is 
very important to do. In line with that situation, Cunningsworth (1995: 5) says that no course book designed for a general market can be completely ideal for particular group of learners, but the purpose of selecting and evaluating the textbook is to find the best possible fits. Teachers have to choose and to evaluate the textbook based on the curriculum and the students' need. Ur $(1996,183)$ states that some schools only take the course book for granted and others might not use at all. Therefore, evaluating the course book is crucial to find out the weakness and the strength of the course book. It is supported by Cunningsworth (1995: 14) who says that the reason to evaluate a course book is to identify strengths and weaknesses in course book already in use, so that finest use can be made of their strong points, whilst their weaker areas can be strengthened through adaptation or by substituting material from other books. Then, teachers may adjust whether the course book is good to be used in the teaching learning process. It is in line with Fitzpatrick and friends (1997:13) who says that the main purpose of evaluation is to provide judgments about the value or whatever is being evaluated. In this case, thing to be evaluated is a course book. However, Cunningsworth (1995:5) points out that materials or course book evaluation are a complex matter, as there are numerous variables that affect the success or failure of using the course book; therefore, he suggests that it is important to limit the number of criteria used, the number of questions ask to convenient proportion, otherwise evaluator or teachers risk being swamped in a sea of detail.

\section{Reading Comprehension Levels}

There have been many efforts to identify structures of cognition or taxonomies. Bloom (1956) defines taxonomy as a system of classification usually in a hierarchical structure. For the teacher, the taxonomy provides a system of classification, usually in a hierarchical structure, for cognitive processes of learners. These classification systems enable teachers to build learning experiences on increasingly complex levels of thinking. Classifying levels of thinking and kinds of knowledge provide useful structures for curriculum decision making on what is to be learned (curriculum) and how it should be taught in the classroom. Knowing how to use taxonomies enables educators to build precise objectives for effective lesson planning.

Bloom (1956) finds that people are too often stuck at the lowest levels of the reading taxonomy and never move onto the higher levels, which are the higher orders of thinking. Bloom's taxonomy is known as the best known classification system. There are six levels of Bloom taxonomy: knowledge, comprehension, application, analysis, synthesis and evaluation. However, the Bloom's taxonomy has been revised by Anderson and Krathwohl (2000) with new terms and emphasis. The six levels of reading taxonomy by Anderson and Krathwol (2000) are:

1. Remembering : Retrieving, recalling, or recognizing knowledge from longterm memory.

2. Understanding : Constructing meaning through interpreting, inferring, and explaining.

3. Applying : Carrying out or using a procedure through executing or implementing. 
4. Analyzing : Breaking material into parts; determining how the parts relate to one another and to an overall structure or purpose through differentiating, organizing and attributing.

5. Evaluating : Making judgments based on criteria and standards through checking and critiquing.

6. Creating : Putting elements together to form a coherent or functional whole; reorganizing elements into a new pattern or structure through generating, planning or producing.

\section{Method}

This study was a kind of qualitative research since the researcher described and analyzed the data collected and the result of the study in words rather than numbers. Titscher and friends (2000: 6) state that evaluation methods regulate the transformation of data information and further restrict the opportunities for inference and interpretation.

The writer of a qualitative research or coursebook evaluation needed to consider the objectivity of the study since the result of the study or evaluation should be accountable. Therefore, the researcher of this study used a triangulation for the sake of the objectivity of the study. According to Heigham and Croker (2009:11), triangulation is "obtaining different perspectives on a phenomenon by gathering data from different participants". This study used the method of document analysis since the other participant who triangulated this study used the same checklist used by the researcher to evaluate reading exercises in the Look Ahead coursebooks.

The checklist used to judge comprehension levels of the exercises were the Anderson and Krathwol's Reading Comprehension Taxonomy, which provides a detailed classification of reading comprehension levels.

\section{Findings}

Comprehension of reading exercises are important to be evaluated since the exercises should help students to comprehend the meaning of a text. This study judged comprehension levels of the exercises using Anderson and Krathwol's Reading Comprehension Taxonomy. There are six levels of their Reading Taxonomy: Remembering, Understanding, Applying, Analyzing, Evaluating, and Creating. The first three levels are considered as lower-order thinking level while the last three levels are considered as higher-order thinking level. The comprehension taxonomy of the exercises in Look Ahead coursebooks are described below.

\subsection{The Reading Exercises in Look Ahead 1}

There were twenty five reading passages presented in Look Ahead 1. Each passage is followed with reading comprehension questions. The researcher found 126 reading comprehension questions following all the reading passages in the course book. 
Table 1. Comprehension Levels of Exercises in Look Ahead 1

\begin{tabular}{|c|c|c|c|c|}
\hline \multirow[t]{2}{*}{ No } & \multirow{2}{*}{$\begin{array}{c}\text { Reading } \\
\text { Taxonomies in } \\
\text { KTSP }\end{array}$} & \multirow{2}{*}{$\begin{array}{c}\text { Reading Exercises in Look Ahead } \\
1 \\
\text { (examples) }\end{array}$} & \multicolumn{2}{|c|}{ Compatibility } \\
\hline & & & Percentage & Frequency \\
\hline 1 & Remembering & Where did the woman keep her? & $53 \%$ & 67 \\
\hline 2 & Understanding & - What is the text talking about? & $33 \%$ & 42 \\
\hline 3 & Applying & None & $0 \%$ & 0 \\
\hline 4 & Analyzing & - What is the structure of the text? & $10 \%$ & 12 \\
\hline 5 & Evaluating & $\begin{array}{l}\text { - Do you like the story? Why/ why } \\
\text { not? }\end{array}$ & $3 \%$ & 4 \\
\hline 6 & Creating & - Arrange this jumbled paragraph! & $1 \%$ & 1 \\
\hline
\end{tabular}

The reading comprehension questions are aimed to guide the students to comprehend the message of the text. Adopted from Anderson and Krathwol (2000), there are six levels of reading taxonomy defined in this study. They are remembering, understanding, applying, analyzing, evaluating and creating. The reading exercises which are presented in Look Ahead 1 are evaluated and categorized based on the six reading taxonomies defined.

1. Remembering

Concerning the criterion remembering, it gets 53\% with 67 frequency. There are 67 questions that require students to retrieve, to recall or to recognize knowledge from memory. This level gets the highest number of questions.

One of the examples is exercise following the eight reading passage presented in Unit 2 entitles Thumbelina. There are eight questions to guide students to comprehend the text. Five of the eight questions require students to remember the detail information from the passage, such as "Where did the woman keep her?"

2. Understanding

With regard to the criterion of understanding, it gets 33\% with a frequency of 44 . There are 44 questions guide students to construct meaning through interpreting, inferring, and explaining.

For example, exercise following the twelfth reading passage entitles The Gift presented in Unit 4. It is followed with seven questions to help students to comprehend the message of the text. Three of the questions require students to make inference from the text, such 
as "What is the text talking about?"

3. Applying

According to the criterion of applying, there are $0 \%$ of the reading exercises that guide students to carry out a procedure through executing or implementing. In other words, none of the reading passages is followed with questions or tasks that require students to achieve this level.

4. Analyzing

Concerning the criterion of analyzing, there are $10 \%$ of the reading exercises that guide students to make analysis from the information in the text. So, there are twelve questions guide students to break material or concepts into parts.

For example, exercise following the sixth reading passage presented in Unit 2. There are seven questions following the reading passage to guide the readers to comprehend the message of the text. Two of the questions help students to make an analysis from the text, such as "What is the structure of the text?"

5. Evaluating

With regard to the criterion of evaluating, there are $3 \%$ of the reading exercises guiding students to make the evaluation of the text. In other words, there are four questions that guide students to make judgments for the text through checking or critiquing, such as "Do you like the story? Why/ why not?"

6. Creating

According to the criterion creating, there are $1 \%$ of the reading exercises that ask students to achieve this reading taxonomy. In other words, there is only one question that guides students to comprehend the passage by reorganizing elements into a new pattern or structure through generating, planning or producing: Arrange this jumbled paragraph!

\subsection{The Reading Exercises in Look Ahead 2}

Similar to Look Ahead 1, this course book consists of twenty five reading passages. Each reading passage is followed by exercises that guide the students to comprehend the message of the text. There are 132 reading comprehension questions found in Look Ahead 2.

Table 2. Comprehension Levels of Exercises in Look Ahead 2

\begin{tabular}{|l|l|l|c|c|}
\hline No & $\begin{array}{c}\text { Reading Taxonomies in } \\
\text { KTSP }\end{array}$ & \multicolumn{1}{|c|}{$\begin{array}{c}\text { Reading Exercises } \\
\text { in Look Ahead 2 (examples) }\end{array}$} & \multicolumn{2}{|c|}{ Compatibility } \\
\cline { 4 - 5 } & Remembentage & Frequency \\
\hline 1 & $\begin{array}{c}\text { - What does AFI offer to TV } \\
\text { viewers? }\end{array}$ & $39 \%$ & 51 \\
\hline 2 & Understanding & - What is the message of the & $30 \%$ & 40 \\
\hline
\end{tabular}




\begin{tabular}{|l|l|l|c|c|}
\hline 3 & Applying & $\begin{array}{l}\text { story? } \\
\text { Practice reading the story } \\
\text { aloud! }\end{array}$ & $2 \%$ & 3 \\
\hline 4 & Analyzing & $\begin{array}{l}\text { - What is the purpose of the } \\
\text { writer telling this story? }\end{array}$ & $21 \%$ & 28 \\
\hline 5 & Evaluating & $\begin{array}{l}\text { Do you agree with the text? } \\
\text { Why/ why not? }\end{array}$ & $8 \%$ & 10 \\
\hline 6 & Creating & \begin{tabular}{l} 
None \\
\hline
\end{tabular} & $0 \%$ & 0 \\
\hline
\end{tabular}

In this study, the reading exercises are evaluated in order to find out comprehension levels of the reading exercises based on the Reading Comprehension Taxonomy by Anderson and Krathwol (2000). Here is the qualitative description of the findings:

\section{Remembering}

Similar to Look Ahead 1, many reading passages presented in this course book are guided with questions that require students to remember the stated details of the text. There are $39 \%$ of the reading exercises that asks students to achieve this level. In other words, there are fifty questions that require the students to retrieve, to recall or to recognize the stated details in the passage. One of the examples is what does AFI offer to TV viewers?

2. Understanding

With regard to the criterion of understanding, there are $30 \%$ of the reading exercises that require students to construct meaning by interpreting, inferring or explaining. In other words, there are forty questions guide students to achieve this level, such as what is the message of the story?

3. Applying

With respect to the criterion applying, only $2 \%$ of the reading exercises guide students to achieve this level. So, there are only three questions that require the students to comprehend the meaning of the passage by carrying out a procedure through executing or implementing, such as Practice reading the story aloud!

4. Analyzing

Concerning the criterion of analyzing, there are $21 \%$ of the reading exercises guides students to make analysis of the text. So, there are twenty eight questions that help students to comprehend the message of the text by analyzing the text, for example what is the purpose of the writer telling this story?

5. Evaluating

With regard to the criterion of making evaluation, there are $8 \%$ of the reading exercises 
that guide students to make evaluation of the text. In other words, there are ten questions that guide students comprehend the message of the text by making judgments based on criteria and standards through checking and critiquing, for example do you agree with the text? Why/ why not?

6. Creating

Concerning the criterion of creating, there are $0 \%$ of the reading exercises that guide students to comprehend the message of the text by creating. In other words, none of the reading passages is followed by question or task that guides students to reorganize elements into a new pattern or structure through generating, planning or producing.

\subsection{The Reading Exercises in Look Ahead 3}

This course book consists of twenty reading passages. Each reading passage is followed by comprehension exercise. There are 112 questions found in Look Ahead 3 to comprehend the message of the text.

Table 3. Comprehension Levels of Exercises in Look Ahead 3

\begin{tabular}{|c|c|c|c|c|}
\hline \multirow[t]{2}{*}{ No } & \multirow{2}{*}{$\begin{array}{c}\text { Reading Taxonomies in } \\
\text { KTSP }\end{array}$} & \multirow{2}{*}{$\begin{array}{c}\text { Reading Exercises in } \\
\text { Look Ahead } 3 \text { (examples) }\end{array}$} & \multicolumn{2}{|c|}{ Compatibility } \\
\hline & & & Percentage & Frequency \\
\hline 1 & Remembering & Where was Duke Senior? & $51 \%$ & 57 \\
\hline 2 & Understanding & $\begin{array}{l}\text { - What lesson can you } \\
\text { learn from the story? }\end{array}$ & $32 \%$ & 37 \\
\hline 3 & Applying & Read the story aloud! & $2 \%$ & 2 \\
\hline 4 & Analyzing & $\begin{array}{l}\text { Which of these is the } \\
\text { purpose of the text? }\end{array}$ & $9 \%$ & 10 \\
\hline 5 & Evaluating & $\begin{array}{l}\text { - How would you rate this } \\
\text { film? Excellent, very } \\
\text { good, quite good, good, } \\
\text { or boring? }\end{array}$ & $3 \%$ & 3 \\
\hline 6 & Creating & $\begin{array}{l}\text { - Create the "issue" and } \\
\text { "conclusion" of this text! }\end{array}$ & $3 \%$ & 3 \\
\hline & & & $100 \%$ & 112 \\
\hline
\end{tabular}

The researcher of this study tried to find out the comprehension levels of the exercises. Here is the qualitative description of the findings: 
1. Remembering

Similar to the other two series of Look Ahead, this level gets the highest number of questions. There are $51 \%$ of the reading exercises compatible with this level. In other words, there are fifty seven questions that guide the students to retrieve, recall, or recognize knowledge from long-term memory, for example where was Duke Senior?

2. Understanding

With regard to the criterion of understanding, there are only $32 \%$ of the reading exercises that guide students to construct meaning through interpreting, inferring, and explaining. So, there are thirty seven questions that help students to achieve this level, such as what lesson can you learn from the story?

3. Applying

According to the criterion of applying, there are only $2 \%$ of the reading exercises that guide students to achieve this level. In other words, two questions ask the students to carry out or use a procedure through executing or implementing, such as Read the story aloud!

4. Analyzing

Concerning the criterion of analyzing, $9 \%$ of the reading exercises guide students to break material into parts; determine how the parts relate to one another and to an overall structure or purpose through differentiating, organizing and attributing. In other words, there are ten questions that guide students to achieve this level, for example which of these is the purpose of the text?

5. Evaluating

With regard to the criterion of evaluating, there is only $3 \%$ of the reading exercises that guide students to make the evaluation of the text. In other words, there are three questions ask students to make judgments based on criteria and standards through checking and critiquing, for instance How would you rate this film? excellent, very good, quite good, good, or boring?

6. Creating

Concerning the criterion of creating, there are $3 \%$ of the reading exercises that guide students to put elements together to form a coherent or functional whole; reorganize elements into a new pattern or structure through generating, planning or producing. In other words, three questions or tasks in the course book require students to achieve this level, such as Create the "issue" and "conclusion" of this text!

\section{Summary}

The graphic below summarized the comprehension levels of the reading exercises in Look Ahead 1, 2, and 3 based on the Anderson and Kratwol's Reading Comprehension Taxonomy. 


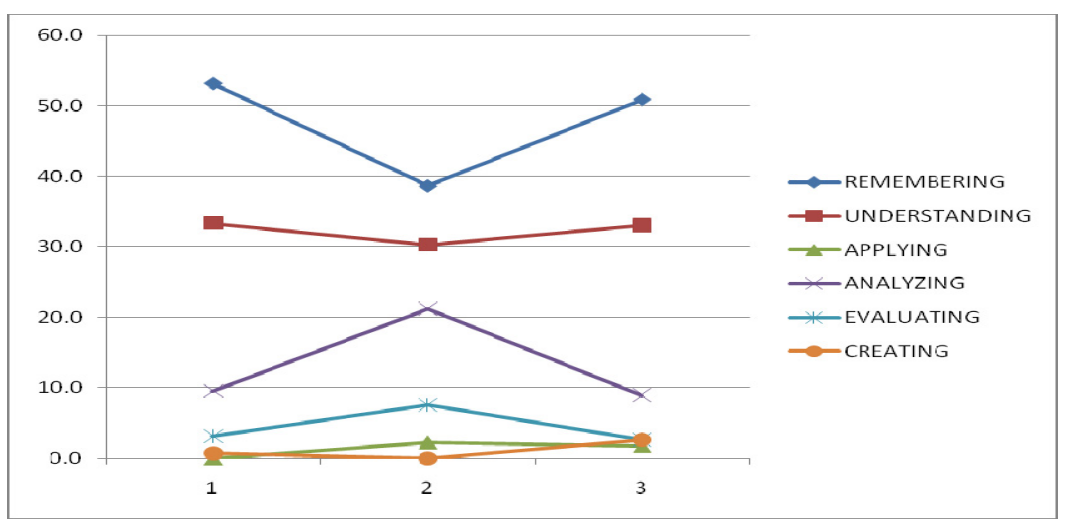

Figure 1. Summary of Comprehension levels of the Reading Exercises in Look Ahead coursebooks

To sum up, most of the reading exercises presented in all the series of Look Ahead guide students to achieve the lowest cognitive level of the reading taxonomy. It is the level of Remembering which requires students to retrieve, recall, or recognize knowledge from long-term memory. In detail, there are $53 \%$ of the reading exercises in Look Ahead 1 that provide this kind of questions. Then, Look Ahead 2 presents 39\% reading questions to achieve this level. Finally, there are 51\% reading questions in Look Ahead 3 ask the students to achieve this level.

Next, the results show that more than $30 \%$ of the reading exercises in all the series of Look Ahead guides students to achieve the Understanding level. This level is still considered as lower cognitive level of the reading taxonomy. It requires students to construct meaning through interpreting, inferring, and explaining. Look Ahead 1 presents $33 \%$ reading exercises to achieve this level. Then, there are 30\% reading exercises in Look Ahead 2 presented to achieve this level. Finally, Look Ahead 3 presents $32 \%$ reading exercises to achieve this level.

Then, the researcher discovered that the third level of reading taxonomy is not well presented in the series of Look Ahead. The third level is applying which requires students to carry out or to use a procedure through executing or implementing. There are only $2 \%$ reading exercises in Look Ahead 2 and Look Ahead 3 that guides students to achieve this level. In addition, none of the reading exercises in Look Ahead 1 achieves this level.

The fourth level of the reading taxonomy is Analyzing. This level is considered as higher cognitive level which requires students to break material into parts; determine how the parts relate to one another and to an overall structure or purpose through differentiating, organizing and attributing. Look Ahead 1 presents 10\% reading exercises to achieve this level. Then, there are $21 \%$ reading exercises presented in Look Ahead 2 to achieve this level. Finally, Look Ahead 3 presents $9 \%$ reading exercises to achieve this level.

Then, the fifth level of the reading taxonomy is evaluating. This level is also considered as higher cognitive level of the reading taxonomy. It requires students to make judgments based 
on criteria and standards through checking and critiquing. The reading exercises to achieve this level in each Look Ahead course book are presented less than 10\%. Look Ahead 1 and Look Ahead 3 only presents 3\% reading exercises to achieve this level while Look Ahead 2 presents $8 \%$ of the reading exercises.

Finally, the sixth level of the reading taxonomy is creating. It is the highest cognitive level of reading taxonomy. It requires students to put elements together to form a coherent or functional whole; reorganize elements into a new pattern or structure through generating, planning or producing. The series of Look Ahead present less than $5 \%$ of the reading exercises to achieve this level. In detail, Look Ahead 1 only presents $1 \%$, and Look Ahead 3 presents 3\%. In addition, none of the reading exercises in Look Ahead 2 is presented to achieve this level.

In short, more than $70 \%$ reading exercises in the series of Look Ahead are presented to achieve the lower- cognitive level of the reading taxonomy. While, there are less than $30 \%$ reading exercises presented in the course books to achieve the higher- cognitive level of the reading taxonomy. It can be seen at the graphic below.

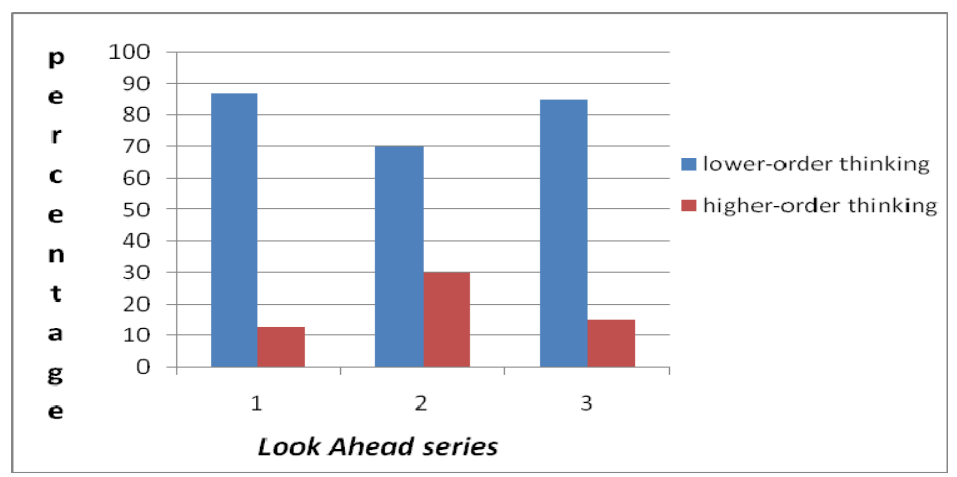

Figure 2. Cognitive levels of the comprehension exercises in Look Ahead

\section{Discussion}

Course book is used to be a source for the students to achieve the goals of learning. It is supported by some theorists such as Ansary and Babaii (2002) who say that using course book is a support to achieve the goals of a program. Therefore, evaluation toward the course book is very important to do to discover the strength and the weakness of the course book. Then, teachers should strengthen the weakness in order to achieve the learning's goal. It is in line with Cunningsworth (1995) who argues that the reason to evaluate a course book is to identify strengths and weaknesses in course book, so that finest use can be made of their strong points, whilst their weaker areas can be strengthened through adaptation or by substituting material from other books.

The goal of learning is stated as basic competence in the syllabus. Previous curriculum in Indonesia did not only employ basic competencies but also the indicators of the basic 
competencies. So, students could claim that they had achieved the goal of learning if they achieved the indicators. However, the latest curriculum in this country, which is called KTSP, does not explicitly employ indicators of learning that should be achieved by the students. The KTSP only officially states the standard and basic competencies as the goals of learning that should be achieved by students. The indicators are free to be developed by each school.

Therefore, to make an evaluation toward the reading materials in the evaluated course book of this study, the researcher uses reading taxonomy as the indicators to discover to what extent the course book achieves the goal of English learning. According to Bloom (1956), taxonomy is a system of classification usually in a hierarchical structure. Bloom's taxonomy is the one often used in researches. However, the Bloom's taxonomy has been revised by Anderson and Krathwol (2000).

There are six levels of the reading taxonomy suggested to be achieved by a learner: remembering, understanding, applying, analyzing, evaluating, and creating. Those levels are arranged from the lowest to the highest. The first three levels are considered as the lowercognitive levels while the last three levels are considered as the higher- cognitive levels. Students of senior high school are prepared to enter university level which needs students to use their critical thinking. Therefore, students of senior high school are not only suggested to learn the lower- cognitive levels but also the higher- cognitive levels in order to prepare them to use their critical thinking when they enter the university level.

The first level is remembering. It is the lowest - cognitive level of reading taxonomy. Students of the second and the third grade are suggested to learn fewer questions for this level rather than the first grade students. This level decreases from Look Ahead 1 to Look Ahead 2 while it increases again from Look Ahead 2 to Look Ahead 3. Therefore, a logical order cannot be assigned for this level in the course books.

Then, the second level of reading taxonomy is called Understanding. This level is still considered as lower- cognitive levels. Therefore, the second and the third grade students should learn this level less than the first grade students. However, the result shows that the series of Look Ahead presents one third of the reading questions to achieve this level. So, the course books do not fit a logical order.

Next, the third level of reading taxonomy is called Applying. This level is also considered as lower- cognitive levels. Therefore, the number of questions to achieve this level should be decreased from the first to the second and the third grade. However, the result shows that Look Ahead 2 and Look Ahead 3 present similar number of questions to achieve this level. They present $2 \%$ reading questions to achieve this level while none of the questions achieves this level in Look Ahead 1. Therefore, a logical order cannot be assigned for this level in the course books. In addition, the number of questions to achieve this level is too low. Students need more exercises to achieve this level.

Then, the fourth level of reading taxonomy is called Analyzing. This is considered as highercognitive levels. Therefore, this level should be increased from the first to the second and the third grade. The result shows that this level increases from Look Ahead 1 to Look Ahead 2 but 
it decreases again from Look Ahead 2 to Look Ahead 3. Therefore, a logical order cannot be assigned for this level in the course books. In addition, the number of this level in Look Ahead 3 is too low. There are only 10\% reading questions achieve this level in that course book while the third grade students need more challenging exercises to activate their critical thinking.

Next, the fifth level of reading taxonomy is called Evaluating. This is considered as highercognitive levels. So, the second and the third grade students should get more questions to achieve this level more than the first grade students. The result shows that this level increases from Look Ahead 1 to Look Ahead 2 but it decreases again from Look Ahead 2 to Look Ahead 3. Therefore, a logical order cannot be assigned for this level in the course books. In addition, the number of this level in the series of Look Ahead is too low. Look Ahead 1 and Look Ahead 3 only presents $3 \%$ reading questions to achieve this level while Look Ahead 2 provides $8 \%$ reading questions to achieve this level. So, they are not good course books to prepare students to enter university level. Students need to learn more higher- cognitive levels to activate their critical thinking in order to prepare them for the university level.

Finally, the highest level of the reading taxonomy is creating. This is considered as the higher- cognitive level. So, senior high school students need to learn this level although it is the most difficult one. The result shows that Look Ahead 3 presents questions in this level more than Look Ahead 1 and Look Ahead 2. However, the number of the questions of this level is too low. Look Ahead 3 only presents 3\% reading questions while Look Ahead 1 only presents $1 \%$ reading questions to achieve this level. Moreover, none of reading questions in Look Ahead 2 achieves this level. So, the series of Look Ahead are not good course book to guide students to achieve this highest- cognitive level of the reading taxonomy.

According to Cunningswoth (1995), materials in the course book should be graded from simple to complex. So, the materials for the second grade should be more complex than the materials for the first grade while the materials for the third grade should be more complex than the materials for the first and the second grade. However, simple exercises are more presented in Look Ahead 3 rather than in Look Ahead 2. The failure of introducing exercises at higher comprehension levels will hinder the development of the students' comprehension skills.

\section{Conclusion and Suggestion}

The comprehension levels of reading exercises in Look Ahead coursebooks are not proportional. The lower-order thinking exercises dominated the exercises, especially for the remembering level. While, there are only few higher-order thinking exercises presented. It shows that the coursebooks fail to provide reading exercises that promote students' critical thinking as demanded in the English syllabus of KTSP, as the latest curriculum in Indonesia. This failure will hinder the development of the students' comprehension skills, and further, their reading skills.

In regard of the result of the study, teachers are suggested to add some exercises to achieve the higher levels of reading taxonomy: analyzing, evaluating, and creating. Students of senior high school are prepared to enter university level; therefore, the students need to learn to 
activate their critical thinking by learning the higher cognitive levels of reading taxonomy. In addition, teachers are also suggested to add some exercises to achieve the applying level since there are only $2 \%$ reading exercises of this level presented in Look Ahead 2 and Look Ahead 3 while none is presented in Look Ahead 1.

Further study may also be done for evaluating reading exercises in other English course books to see the comprehension levels. In addition, study on the types of exercises (multiple choice, true or false, or comprehension questions) may also be done.

\section{References}

Abbot, G., \& friends. (1981). The Teaching of English as an International Language: A Practical Guide. Great Britain: William Collins Sons \& Co, Ltd.

Alderson, J. C. (2000). Assessing Reading. New York: Cambridge University Press.

Anderson, L. W., \& D. R. Krathwohl, Eds. (2000). A Taxonomy for Learning, Teaching, and Assessing: A Revision of Bloom's Taxonomy of Educational Objectives. New York, Longman.

Ali, Nai'ma Mosa. (2010). An Evaluation of the Reading Text and Exercises in Sb and WB of English for Palestine- grade 9. Gaza: Deanery of Higher Education.

Badan Standar Nasional Pendidikan (BSNP). (2006). Model Kurikulum Tingkat Satuan Pendidikan. Jakarta: Departemen Pendidikan Nasional.

Badan Standar Nasional Pendidikan (BSNP). (2007). Standar Isi, Standar Kompetensi Lulusan Mata Pelajaran Bahasa Inggris. Jakarta: Departemen Pendidikan Nasional.

Bloom, B. S. (Ed.), Engelhart, M. D., Furst, E. J., Hill, W. H., \& Krathwohl, D. R. (1956). Taxonomy of educational objectives: Handbook I: Cognitive domain. New York: David McKay.

Brown, H. Douglas. (2000). Principles of Language Learning and Teaching. New York: Addison Wesley Longman, Inc.

Brown, H. Douglas. (2001). Teaching by Principles: An Interactive Approach to Language Pedagogy, Second Edition. New York: Addison Wesley Longman, Inc.

Brown, H. Douglas. (2004). Language Assessment. New York: Addison Wesley Longman, Inc.

Butt, David and friends. (2000). Using Functional Grammar. Sydney: Macquarie University.

Celce-Murcia, Marianne. (1991). Teaching English as a Second or Foreign Language. Massachusetts: Heinle and Heinle Publishers.

Chastain, K. (1971). The Developmentof modern Language Skills: Theory to Practice.Philadelphia: The Centre for Curriculum Development.

Chitravelu, N., Saratha S., and Teh S.C. (2005). ELT Methodlogy, rinciples and Practice. Malaysia: Oxford Fajar. 
Creswell, J. (2003). Research Design. USA: SAGE Publications.

Cunningsworth, A. (1995). Choosing Your Course book. Oxford: Heinemann.

Daoud, A. and Celce-Murcia, M. (1979). Selecting and Evaluating a Textbook. In M. Celce-Murcia and L. McIntosh (Eds.), Teaching English as a Second or Foreign Language. Cambridge, MA: Newbury House Publishers.

DEPDIKBUD. (1993). Lampiran II Keputusan Menteri Pendidikan dan Kebudayaan No. 060/U/ 1993. Jakarta: DEPDIKBUD.

Depdiknas. (2005). Peraturan Pemerintah No. 19 Tahun 2005 Tentang Standar Nasional Pendidikan.Jakarta: Depdiknas.

Depdiknas. (2006). PERMENDIKNAS No. 22. Jakarta: Depdiknas.

Depdiknas. (2006). PERMENDIKNAS No. 23. Jakarta: Depdiknas.

Depdiknas. (2006). PERMENDIKNAS No. 24. Jakarta: Depdiknas.

Dubin, F., \& Olshtain. (1986). Course Design. Cambridge: Cambridge University Press.

Gebhard, J. G. (2000). Teaching English as a Forwign or Second Language: A Teacher Self-Development and Guide. Ann Arbor: The University of Michigan Press.

Grabe, W., \& F. Stoller. (2002). Teaching and Researching Reading. Great Britain: Pearson Education.

Harjanto, I., \& Pramono, H. (2011). The Evaluation of the School Electronic Books: Developing English Competencies for Senior High Schools. Surabaya: Widya Mandala Catholic University.

Harmer, J. (1998). How to teach English. Harlow: Longman.

Harmer, J. (2001). The Practice of English Language Teaching. Harlow: Longman.

Haris, A. J. (1962). Effective Teaching of Reading. New York: David McKay Company, Inc.

Helena, Agustien. (2004). The 2004 English Curriculum in a Nutshell. A paper presented at the 50th Anniversay of Universitas Negeri Malang.

Heigham, J., \& Robert A. C. (2009). Qualitative Research in Applied Linguistics. UK: Palgrave Macmillan.

Higgs, Theodore V. (1982). Curriculum, Competence and the Foreign Language Teacher. USA: National Textbook Company.

Litz, D. (2005). Textbook Evaluation and ELT Management: A South Korean Case Study. Asian EFL Journal, $p p$ 43-45. Retrieved on May 2, 2011 from http://www.asian-efl-journal.com/Litz_thesis.pdf

Nunan, D. (1988). Syllabus Design. Oxford: Oxford University. 
Nuttal, C. (1996). Teaching Reading Skills in a Foreign Language. Oxford: Macmillan Education.

Renandya, W. (2003). Methodology and Materials Design in Language Teaching. Singapore: SEAMEO Regional Language Centre.

Richard, Jack C. (2001). Curriculum Development in Language Teaching. Cambridge: Cambridge University Press.

Richard, \& Renandya. (2002). Methodology in Language Teaching: An Anthology of Current Practice. Cambridge: Cambridge University Press.

Ruddell, Martha R. (2008). Teaching Content Reading and Writing. USA: John Weley \& Sons, Inc.

Sheldon, L. E. (1988). Evaluating ELT Textbooks and Materials. ELT Journal 42/ 4.

Singer, M., \& John T. (1999). National Research Council on Developingthe Capacity to Select Effective Instructional Materials. USA: National Academy Press.

Sutedjo, B. (2010). Membentang Sayap Menuju Harapan. Surabaya: Unesa University Press.

Sudarwati, Th.M., \& Eudia Grace. (2007). Look Ahead 1: An English Course for Senior High School Students Year X. Jakarta: Erlangga.

Sudarwati, Th.M., \& Eudia Grace. (2007). Look Ahead 2: An English Course for Senior High School Students Year XI. Jakarta: Erlangga.

Sudarwati, Th.M., \& Eudia Grace. (2007). Look Ahead 3: An English Course for Senior High School Students Year XII. Jakarta: Erlangga.

Titscher, S., Meyer M., Wodak, \& Vetter. (2000). Methods of Text and Discourse Analysis. London, England: Sage Publication.

Tomlinson, Brian. (1998). Materials Development in Language Teaching. Cambridge: Cambridge University Press.

Ur, Penny. (1996). A Course in Language Teaching: Practice and Theory. Cambridge: Cambridge University Press.

\section{Copyright Disclaimer}

Copyright for this article is retained by the author(s), with first publication rights granted to the journal.

This is an open-access article distributed under the terms and conditions of the Creative Commons Attribution license (http://creativecommons.org/licenses/by/3.0/). 